\title{
MENINGKATKAN HASIL BELAJAR PKn KOOPERATIF TIPE JIGSAW MURID KELAS IV SD NEGERI SUDIRMAN IV
}

\author{
Nur Afni \\ Prodi PGSD FKIP Universitas Islam Makassar \\ Email: afniwahid777@gmail.com
}

\begin{abstract}
Pada dasarnya setiap guru menginginkan dalam proses pembelajaran berjalan aman dan kondusif, oleh karena itu diperlukan suatu metode dan strategi yang mampu meningkatkan hasil belajar siswa yang positif yang dapat menunjang kegiatan pembelajaran. Sebenarnya guru telah berusaha menciptakan pembelajaran agar siswa lebih aktif, diantaranya mengerjakan lembar kerja siswa (LKS), menggunakan media yang ada di sekolah, dan mengunakan metode tanya jawab. Penelitian ini bertujuan untuk mengetahui apakah penerapan model pembelajaran kooperatif tipe Jigsaw dapat meningkatkan hasil belajar Pendidikan IPS pada siswa kelas IV SDN Sudirman IV Makassar. Pendekatan penelitian metode penelitian kuantitatif. Jenis penelitian yang digunakan adalah penelitian tindakan kelas. Data diperoleh dengan menggunakan lembar observasi dan tes hasil belajar. Data yang diperoleh dianalisis dengan menggunakan analisis tes hasil belajar dan statistik infrensial. Pembelajaran dengan pembelajaran kooperatif tipe Jigsaw dampak positif terhadap peningkatan hasil belajar PKn dan terjadi perubahan sikap yang positif bagi murid kelas kelas IV selama pelaksanaan tindakan. Hal ini dapat terlihat pada hasil belajar PKn murid kelas melalui pembelajaran kooperatif tipe Jigsaw mengalami peningkatan. Hal ini terlihat dari nilai rata-rata setelah dilaksanakannya tindakan kelas pada siklus I, kemudian nilai rata-rata meningkat dari skor ideal yang akan dicapai setelah dilaksanakannya tindakan kelas pada siklus II. Ketuntasan Hasil belajar sains murid kelas IV SDN Sudirman IV Makassar meningkat.
\end{abstract}

Kata kunci: Meningkatkan hasil belajar PKn melalui pembelajaran Kooperatif tipe Jigsaw.

\section{PENDAHULUAN}

Pendidikan Nasional di Indonesia menurut Undang-Undang RI No. 20 tahun 2003, Bab I Pasal 1 (1) pendidikan adalah usaha sadar dan terencana untuk mewujudkan suasana belajar dan proses pembelajaran agar peserta didik secara aktif mengembangkan potensi dirinya untuk memiliki kekuatan spritual keagamaan, pengendalian diri, kepribadian kecerdasan, akhlak mulia, serta keterampilan yang diperlukan dirinya, masyarakat, bangsa dan negara. UNESCO menjelaskan bahwa pendidikan pada abad ini harus diorientasikan terhadap pencapaian 4 pilar pembelajaran yaitu : "(1) Learning to know (belajar untuk tahu), (2) Learning to do (belajar untuk melakukan), (3) Lerning to be (belajar untuk menjadi diri sendiri), (4) learning to live together (belajar bersama dengan orang lain). (Win Winger, 2000:21)"

Dalam proses belajar mengajar di sekolah khususnya untuk mata pelajaran PKn harus senantiasa berorientasi pada 4 pilar pembelajaran tersebut. Untuk mendapatkan hasil dari proses pendidikan yang maksimal tentunya diperlukan pemikiran yang 
kreatif dan inovatif serta didukung dengan faktor pendanaan yang mencukupi. Inovasi pendidikan tidak hanya pada inovasi sarana dan prasarana pendidikan serta kurikulum saja melainkan juga proses pendidikan itu sendiri. Metode mengajar yang dilakukan oleh guru mempunyai peranan yang sangat penting dalam keberhasilan pendidikan. Penggunaan metode yang tepat akan menentukan keefektifan dan keefesienan dalam proses belajar mengajar. Guru harus senantiasa mampu memilih dan menerapkan metode mengajar yang tepat sesuai dengan pokok bahasan lain: metode ceramah, metode tanya jawab dan metode resitasi. Serentetan metode tersebut bisa dikatakan metode konvensional. Salah satu model pembelajaran yang dimungkinkan mampu mengantisipasi kelemahan model pembelajaran kkonvensional adalah dengan menggunakan model pembelajaran kooperatif tipe Jigsaw. Pembelajaran model ini lebih meningkatkan kerja sama antar siswa. Kelas dibagi menjadi kelompokkelompok belajar yang terdiri dari siswa-siswa yang bekerja sama dalam suatu perencanaan kegiatan. Dalam pembelajaran ini setiap anggota kelompok diharapkan dapat saling bekerja sama dan bertanggung jawab baik kepada dirinya sendiri maupun pada kelompoknya. Berdasarkan latar belakang, maka dapat penulis rumuskan permasalahan yang akan diteliti yaitu :

"Apakah penerapan model pembelajaran kooperatif tipe Jigsaw dapat meningkatkan hasil belajar Pendidikan PKn pada Siswa Kelas IV SD Negeri Sudirman IV Makassar".

\section{TINJAUAN PUSTAKA}

\section{A. Model Pembelajaran Kooperatif Tipe Jigsaw}

Pembelajaran kooperatif merupakan salah satu bentuk pembelajaran yang diyakini keberhasilan peserta didik tercapai jika setiap anggota kelompoknya berhasil. Sistem pembelajaran yang memberi kesempatan kepada anak didik untuk kerja sama dengan temannya dalam tugas-tugas terstruktur disebut sebagai sistem pembelajaran gotong royong atau cooperative learning. Shlomo Sharan (2009:27).

"Sistem pembelajaran gotong royong merupakan alternatif menarik yang bisa mencegah timbulnya keagresifan dalam sistem kompetisi dan keterasingan dalam sistem individu tanpa mengorbankan aspek kognitif. Shlomo Sharan (2009:37)Menurut Asep Jihad, dkk (2008:30-3) pada dasarnya pembelajaran kooperatif adalah :

Suatu proses sederhana tetapi berbeda dengan pembelajaran tradisional dan operasi kelas tradisional. Dalam suatu kelas kooperatif, guru mengorganisasikan kurikulum sekitar tugas atau proyek siswa dalam kelompok kecil”"

Menurut Sholomo Sharan (2009:69) teknik mengajar Jigsaw sebagai metode Cooperative learning:

Teknik ini menggabungkan kegiatan membaca, menulis, mendengarkan dan berbicara. Pendekatan ini bisa juga digunakan dalam beberapa mata pelajaran, seperti Pendidikan Kewarganegaraan, matematika, agama dan bahasa. Teknik cocok untuk semua kelas/tingkatan.Menurut Hisyam Zaini dkk (2008:56) Jigsaw Learning merupakan: Strategi yang menarik untuk digunakan jika materi yang akan dipelajari dapat dibagi-bagi menjadi beberapa bagian dan materi tersebut tidak mengharuskan urutan penyampaian. Kelebihan strategi ini adalah dapat melibatkan seluruh peserta didik dalam belajar dan sekaligus mengajarkan kepada orang lain. 
Teknik mengajar Jigsaw dilakukan dengan cara sebagai berikut:

1. Pengajar membagi bahan pelajaran yang akan diberikan menjadi empat bagian 2.Sebelum bahan pelajaran diberikan, pengajar memberikan pengenalan mengenai topik yang akan dibahas dalam bahan pelajaran untuk hari itu. Pengajar bisa menuliskan topik di papan tulis dan menanyakan apa yang siswa ketyahui mengenai topik tersebut. Kegiatan brainstorming ini dimaksudkan untuk mengaktifkan skemata siswa agar lebih siap menghadapi bahan pelajaran yang baru.3. Siswa dibagi dalam kelompok berempat 4. Bagian pertama bahan diberikan kepada siswa pertama, sedangkan siswa kedua menerima bahan yang kedua, demikian seterusnya. 5 . Kemudian siswa disuruh membaca/mengerjakan bagian mereka masiong-masing. 6. Setelah selesai, siswa saling berbagi mengenai bagian yang dibaca/dikerjakan masing-masing. Dalam kegiatan ini, siswa bisa saling melengkapi dan berinteraksi antara satu dengan yang lain.7. Khusus untuk kegiatan membaca, kemudian mengajar membagikan bagian cerita yang belum terbaca kepada masing-masing siswa. Siswa membaca bagian tersebut.8. Kegiatan bisa diakhiri dengan diskusi mengenai topik dalam bahan pelajaran harei itu. Diskusi bisa dilakukan antara pasangan atau dengan seluruh kelas.

\section{B. Hasil Belajar}

Dalam kamus besar Bahasa Indonesia (1990: 700) hasil diartikan sebagai "sesuatu yang telah dicapai (telah dilakukan, dikerjakan)." Menurut Slameto (1995: 8) "Hasil adalah istilah yang digunakan untuk menunjukkan tingkat keberhasilan yang dicapai oleh seseorang setelah melakukan usaha tertentu, hasil belajar merupakan hasil dari suatu interaksi tindak belajar dan mengajar." Haling (Winkel, 1991: 102) mengemukakan bahwa "hasil belajar yang dihasilkan oleh murid akan memberikan perubahan-perubahan dalam bidang pengetahuan dan pengalaman dalam bidang keterampilan, nilai dan sikap." Slameto (1995: 2) mengemukakan bahwa "belajar adalah suatu proses yang dilakukan seseorang untuk memperoleh suatu perubahan tingkah laku yang baru secara keseluruhan sebagai hasil pengalaman sendiri dalam interaksi dengan lingkungannya." Sedangkan Hamalik (2001: 30) mengatakan bahwa "bukti dari seseorang telah belajar adalah terjadinya perubahan tingkah laku dalam aspek pengetahuan, pengertian, kebiasaan, keterampilan, apresiasi, emosional, hubungan sosial, jasmani, budi pekerti dan sikap."

Sedangkan Sudjana (1997: 28) mengatakan bahwa "belajar adalah suatu proses yang ditandai dengan adanya perubahan pada diri seseorang. Perubahan sebagai hasil proses belajar dapat ditunjukkan dalam berbagai bentuk seperti berubah pengetahuannya, pemahamannya, sikap dan tingkah lakunya, keterampilannya, kecakapan dan kemampuannya, daya reaksinya, daya penerimaannya, dan lain-lain aspek yang ada pada individu." Berdasarkan uraian di atas mengenai kata hasil dan belajar, maka dapat ditarik kesimpulan bahwa hasil belajar adalah merupakan sesuatu yang telah dicapai oleh murid setelah mengalami proses belajar dan terjadi perubahan sikap dalam kurun waktu tertentu dan diukur dengan menggunakan alat evaluasi setelah berinteraksi dengan lingkungan tempat belajarnya.

\section{Hakikat Pembelajaran PKn}

Pendidikan di Indonesia diharapkan dapat mempersiapkan peserta didik menjadi warga negara yang memiliki komitmen kuat dan konsisten untuk mempertahankan Negara Kesatuan Republik Indonesia. Komitmen yang 
kuat dan konsisten terhadap prinsip dan semangat kebangsaan dalam kehidupan bermasyarakat, berbangsa, dan bernegara yang berdasarkan Pancasila dan Undang-Undang Dasar 1945, Konstitusi Negara Indonesia perlu ditularkan, ditingkatkan secara terusmenerus untuk memberikan pemahaman yang mendalam tentang Negara Kesatuan Republik Indonesia. Secara historis, negara Indonesia telah diciptakan sebagai Negara Kesatuan dengan bentuk Republik.

\section{Kerangka Pikir}

Metode kooperatif tipe Jigsaw dimungkinkan termasuk salah satu dari sekian metode mengajar yang baik untuk diterapkan dalam proses belajar mengajar pada mata pelajaran pendidikan kewarganegaraan. Dengan metode ini guru dapat menggali konsep dan pengetahuan dasar yang telah dimiliki oleh seorang siswa dan membangunnya dalam suatu konsep pengetahuan yang benar.

Pembelajaran kooperatif tipe Jigsaw merupakan model pembelajaran kelompok. Dalam proses pembelajaran kooperatif terjadi peristiwa pengajaran teman sebaya (peer teaching) yang cenderung lebih efektif dibandingkan dengan pembelajaran oleh guru. Dalam sistem pembelajaran kooperatif siswa berkesempatan untuk bekerja sama dengan teman untuk mengembangkan diri sedangkan guru hanya sebagai fasilitator.Model pembelajaran kooperatif dikembangkan setidaknya untuk mencapai tiga tujuan dasar yaitu hasil belajar akademik, penerimaan terhadap keragaman dan pengembangan keterampilan sosial.

Dalam pembelajaran kooperatif akan mendorong siswa lebih berperan aktif dalam belajar dengan guru sebagai fasilitator belajar sehingga hasil belajar akan lebioh bermakna bagis siswa. Pada pembelajaran konvensional, guru yang lebih berperan aktif sebagai sumber belajar dan siswa hanya sebagai obyek pembelajaran yang cenderung bersifat pasif. Dengan metode yang berbeda yaitu metode kooperatif tipe Jigsaw dan pembelajaran konvensional seperti terurai di atas akan membawa prestasi siswa yang berbeda.Secara ssitematis paradigma penelitian tersebut dapat digambarkan sebagai berikut:

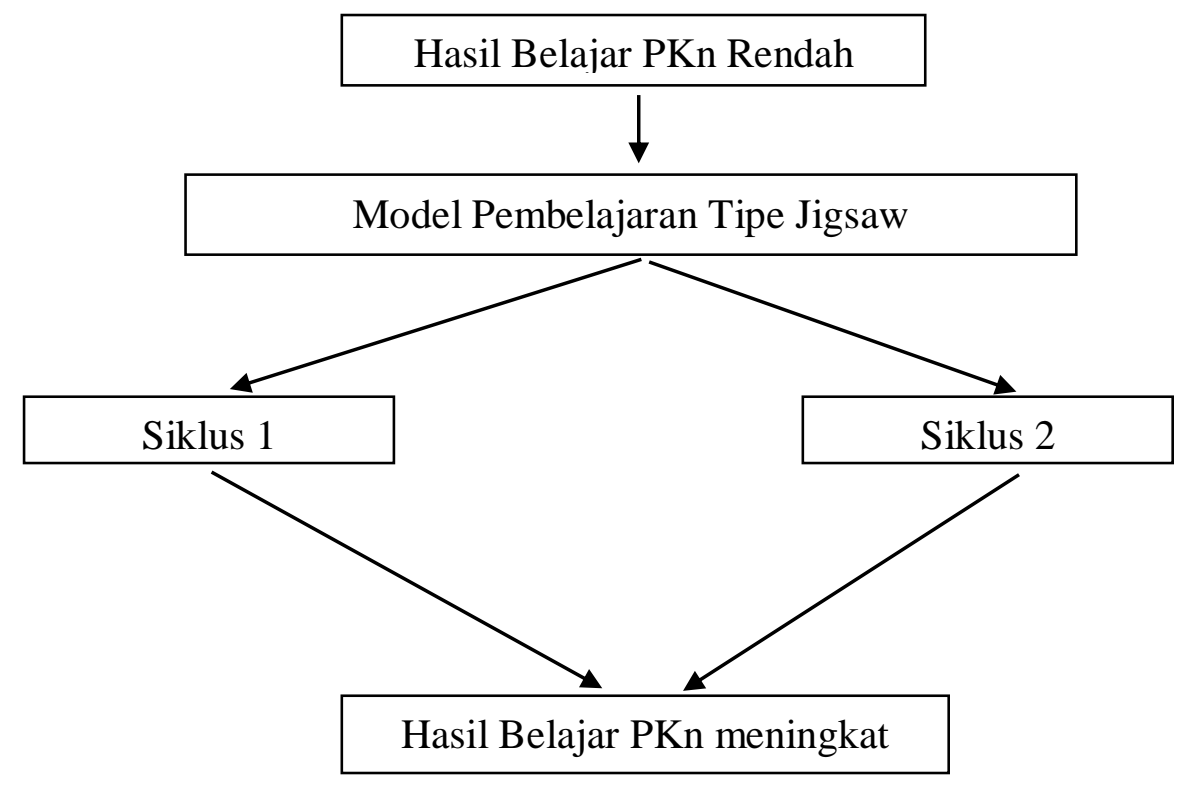




\section{METODE PENELITIAN}

Pendekatan Penelitian yang digunakan yaitu kompilasi antara metode penelitian kualitatif dan metode penelitian kuantitatif. Jenis Penelitian ini adalah penelitian tindakan kelas (Classroom Action Research) yang terdiri atas dua siklus dan disesuaikan dengan materi yang sedang berjalan di sekolah. Tindakan yang dilakukan adalah penerapan pembelajaran kooperatif tipe Jigsaw dalam pembelajaran PKn.

Penelitian Tindakan Kelas (PTK) adalah penelitian tindakan yang dilakukan dengan tujuan memperbaiki mutu praktik pembelajaran di kelas, yang erat kaitannya dengan murid dan pada proses belajar mengajar yang terjadi di kelas.

Dalam penelitian ini yang menjadi fokus adalah siswa kelas IVB SD Negeri Sudirman IV Makassar yang berjumlah siswa yang terdiri dari 20 orang siswa laki-laki dan 15 orang siswa perempuan. Penelitian ini dilaksanakan di SD Negeri Sudirman IV Makassar.Unit analisis yang diselidiki dalam penelitian tindakan ini adalah sebagai berikut kompetensi /kemampuan guru:

1. Menyusun RPP dalam hal ini (lihat lampiran).

2. Pelaksanaan pembelajaran menuliskan hasil pekerjaan murid untuk mengetahui kompetensi guru menyusun RPP yang menggunakan penilaian belajar mengajar.
3. Kemampuan siswa melaksanakan tugas dan menyelesaikan soal.

Proses penelitian tindakan kelas terdiri dari 2 siklus. Tiap siklus dilaksnaakan 4 kali pertemuan ( 2 minggu).

Instrumen penelitian yang digunakan untuk pengumpulan data dalam penelitian tindakan kelas ini berupa:observasi dan Tes. Teknik Analisis data diperoleh dari hasil observasi dianalisis secara kualitatif, sedangkan data mengenai hasil belajar murid dianalisis secara kuantitatif dengan menggunakan statistik deskriptif yaitu skor rata-rata, rentang skor, nilai minimum dan maksimum yang dicapai murid. Indikator keberhasilan penelitian tindakan kelas ini adalah bila skor ratarata hasil tes murid melalui penerapan pembelajaran kooperatif tipe Jigsaw mengalami peningkatan hasil belajar secara klasikal yaitu mencapai $75 \%$ murid yang memperoleh nilai minimum 7,0 dari skor ideal 100 dan terjadi perubahan sikap murid selama mengikuti proses pembelajaran yang ditandai dengan peningkatan keaktifan murid dalam hal kerja sama dalam kelompok, ketertiban dalam kelompok, dan tanggung jawab dalam proses pembelajaran, rasa ingin tahu meningkat. Sehingga pembelajaran kooperatif tipe Jigsaw merupakan salah satu model pembelajaran yang dapat meningkatkan hasil belajar murid.

\section{HASIL PENELITIAN}

\section{A. Deskripsi Hasil Penelitian}

Tabel 1. Perolehan Skor Hasil Belajar Pkn Murid Kelas IV SDN Sudirman IV Makassar pada Siklus I

\begin{tabular}{lc}
\hline Statistik & Nilai Statistik \\
\hline Subjek & 35 \\
\hline Nilai ideal & 10,0 \\
\hline Nilai Rata-rata & 6,70 \\
\hline Nilai Tertinggi & 8,00 \\
\hline
\end{tabular}




\begin{tabular}{cc}
\hline Nilai Terendah & 4,50 \\
\hline Rentang Nilai & 3,50 \\
\hline Sumber:
\end{tabular}

Sumber: Hasil Analisis Data Hasil Belajar

Tabel 2. Deskripsi Ketuntasan Hasil Belajar Pkn Murid Kelas IV SDN Sudirman IV Makassar Siklus I

\begin{tabular}{|c|c|c|c|}
\hline Skor & Kategori & Frekuensi & Persentase \\
\hline $0-69$ & Belum Tuntas & 17 & 42,50 \\
\hline $70-100$ & Tuntas & 18 & 57,50 \\
\hline & & 35 & 100 \\
\hline
\end{tabular}

Sumber: Hasil Analisis Data Hasil Belajar

Tabel 3. Statistik Skor Hasil Belajar Pkn Murid Kelas IV SDN Sudirman IV Makassar Makassar pada Siklus II

\begin{tabular}{lc}
\hline Statistik & Nilai Statistik \\
\hline Subjek & 35 \\
\hline Nilai ideal & 10,00 \\
\hline Nilai Rata-rata & 8,50 \\
\hline Nilai Tertinggi & 10,00 \\
\hline Nilai Terendah & 6,00 \\
\hline Rentang Nilai & 4,00 \\
\hline
\end{tabular}

Tabel 4. Deskripsi ketuntasan Hasil Belajar Pkn Murid Kelas IV SDN Sudirman IV Makassar pada Siklus II

\begin{tabular}{|c|c|c|c|}
\hline Skor & Kategori & Frekuensi & Persentase \\
\hline $0-69$ & Belum Tuntas & 5 & 12,50 \\
\hline $70-100$ & Tuntas & 30 & 87,50 \\
\hline \multicolumn{2}{|c|}{ Jumlah } & 35 & 100 \\
\hline
\end{tabular}

Sumber: Analisis Data Hasil Belajar

\section{B. Pembahasan Hasil Penelitian}

A. Pembahasan

1. Tahap Perencanaan Siklus

Observasi dasar dilakukan dengan tujuan: (1) untuk mengetahui seberapa besar motivasi siswa mengikuti pelajaran Pendidikan Kewarganegaraan, (2) mengetahui bagaimana reaksi siswa dengan tugas di kelas, (3) mengetahui seberapa banyak siswa yang tidak mengerjakan tugas yang diberikan oleh guru, (4) seberapa banyak siswa yang punya kontribusi dan inisiatif terhadap 
kualitas pembelajaran, dan (5) untuk menentukan metode pembelajaran yang bisa merangsang belajar siswa agar selalu aktif di kelas, seperti bertanya, berdiskusi, menyampaikan ide, gagasan, mengerjakan tugas, dan tetap memiliki motivasi belajar yang tinggi.

1) Tahap Perencanaan

Pada tahap perencanaan kegiatan yang dilakukan adalah sebagai berikut:

a) Membuat rencana persiapan pembelajaran (RPP) untuk setiap pertemuan

b) Merancang dan membuat tugas-tugas yang akan diberikan kepada siswa dalam bentuk LKS

c) Membuat lembar observasi untuk mengaamti kondisi pembelajaran di kelas ketika pelaksanaan tindakan sedang berlangsung

d) Membuat tes kemampuan untuk menyelesaikan soal berdasarkan teks yang diberikan.

\section{2) Pelaksanaan Tindakan}

Secara umum tindakan yang dilakuakn pada setiap siklus adalah :

a) Mengajarkan materi dengan menggunakan model kooperatif tipe Jigsaw sesuai dengan RPP yang telah dirancang

b) Memberikan tugas-tugas kepada siswa setiap akhir pembelajaran di kelas dalam bentuk LKS

\section{3) Observasi dan evaluasi}

Merupakan kegiatan mengamati proses pelaksanaan pembelajaran PKn melalui model kooperatif tipe Jigsaw, serta partisipasi atau sikap belajar siswa dalam mengikuti
PKn melalui model kooperatif tipe Jigsaw.

4) Refleksi merupakan kegiatan mengukur siswa dalam pembelajaran PKn melalui metode kooperatif tipe Jigsaw yang dilakukan secara berkelompok.

Berdasar pada tujuan observasi sebagaimana dikemukakan pada metode penelitian diperoleh data sebagai berikut :1) Motivasi siswa yang mengikuti pelajaran cukup baik jika didasarkan pada kehadiran siswa di kelas yang mencapai $98 \%$;2) tugas yang diberikan di kelas hanya dapat dikerjakan oleh kurang dari $50 \%$ siswa, itupun belum benar. Nampak sebagian besar siswa yang tidak mengerti hanya tinggal diam; 3) reaksi siswa terhadap tugas yang diberikan cenderung bersikap diam, apatis dan tidak ada reaksi positif ditandai masih banyak sswa yang mengerjakan tugas seadanya; 4) Masih banyak siswa tidak belajar sebelumnya atau mempersiapkan diri mengikuti pelajaran.

\section{Hasil Pelaksanaan Tindakan Siklus} I

Pelaksanaan Penelitian Tindakan Kelas Siklus I dilaksanakan selama 2 kali pertemuan dengan fase-fase sebagai berikut:

a. Pada pertemuan pertama (2 jam pelajaran $=70$ menit). Fase pertama, menyampaikan tujuan dan motivasi siswa. Guru menyampaikan tujuan pembelajaran. standar kompetensi untuk materi pelajaran Pendidikan Kewarganegaraan di Kelas IV Semester 2 yaitu Untuk memotivasi siswa, guru memberikan contoh. Fase ini berlangsung lebih kurang 10 menit.

b. Fase kedua, menyajikan informasi. Guru menyajikan informasi tentang 
pengaruh globalisasi terhadap perubahan. Fase ini berlangsung lebih kurang 25 menit.

c. Fase ketiga, mengorganisasi siswa ke dalam kelompok-kelompok belajar. Guru menjelaskan cara pembentukan kelompok arti kerja kelompok dalam pembelajaran model kooperatif learning tipe Jigsaw, dan tata aturan dalam kelompok. Fase ini terlaksanan hingga akhir pertemuan pertama.

d. Pada pertemuan kedua barulah fase keempat sampai keenam dilaksanakan. Fase keempat, guru mengorganisir siswa ke dalam 5 kelompok yang beranggotakan masing-masing 5 orang. Guru membimbing kelompok-kelompok asal dan selanjutnya siswa diberi topik yang berbeda-beda. Topiktopik yang sama akan berkumpul dan menjadi kelompok/tim ahli. Pada saat kelompok ahli terbentuk selanjutnya mengerjakan tugas yang telah diberikan. Fase ini berlangsung lebih kurang 35 menit.

e. Fase kelima, evaluasi. Guru mengevaluasi hasil belajar dalam bentuk tes tertulis.

\section{Hasil Pelaksanaan Tindakan Siklus II}

Hasil penelitian kelas Siklus kedua dilaksanakan selama 2 kali pertemuan. Penerapan model pembelajaran kooperatif tipe Jigsaw pada penelitian ini dilaksanakan oleh seorang peneliti dan berkolaborasi dengan supervisor sebagai observer. Skenario pembelajaran Pendidikan Kewarganegaraan melalui model pembelajaran kooperatif tipe Jigsaw pada Siklus kedua agak berbeda dengan yang dilaksanakan pada Siklus pertama. Dalam hal ini tidak semua fase dilaksanakan pada satu kali pertemuan. Hal ini dilakukan karena materi perjuang tokoh menuju kemerdekaan Indonesia memerlukan waktu yang cukup lama untuk pemberian informasi.
Pembelajaran dilaksanakan sesuai sintaks yang ada, yaitu fase yang dapat dijelaskan sebagai berikut :

a. Pada pertemuan pertama (2 jam pelajaran $=70$ menit). Fase pertama, menyampaikan tujuan dan motivasi siswa. Guru menyampaikan tujuan pembelajaran. Standar kompetensi telah dikemukakan pada Siklus pertama. Guru menyampaikan indikator pencapaian hasil belajar untuk materi pelajaran pengaruh globalisasi terhadap perubahan. Fase ini berlangsung lebih kurang 10 menit.

b. Fase kedua, menyajikan informasi. Guru menyajikan informasi pengaruh globalisasi di lingkungan sekitar. Fase ini berlangsung lebih kurang 30 menit.

c. Fase ketiga, mengorganisasi siswa ke dalam kelompok-kelompok belajar. Kelompok (kelompok asal dan kelompok ahli) yang telah dibentuk sebelumnya, sehingga guru cukup mengingatkan siswa akan aturan kerja kelompok. Selanjutnya pada fase keempat, guru membimbing kelompok-kelompok pada saat berdiskusi. Pada pertemuan kedua, guru langsung memberikan informasi lanjutan dan menjelaskan tentang pelaksanaan model pembelajaran jigsaw. Jadi dalam hal ini fase ke-1 dan ke-2 terlaksana lebih kurang 30 menit. Fase ketiga dan keempat, guru mengorganisasi siswa ke dalam 5 kelompok yang beranggotakan masing-masing 5 orang (kelompok asal).

d. Fase keempat kegiatannya adalah guru menempelkan gambar-gambar contoh-contoh alat atau benda akibat globalisasiyang telah disiapkan guru Guru memberi petunjuk dan penjelasan tenatang pengaruh globalisasi terhadap kehidupan. Siswa dikelompokkan kedalam 5 
anggota secara heterogen dan tiap orang dalam kelompok diberi materi yang berbeda. Tiap orang yang memiliki materi yang sama dari kelompok yang berbeda berkumpul membentuk tim ahli untuk mendiskusikan materi mereka. Setelah selesai anggota tim ahli kembali ke kelompok asal dan bergantian mengajari teman satu tim materi yang mereka kuasai, anggota yang lain mendengar dengan sungguh-sungguh.

e. Fase kelima adalah membimbing kelompok-kelompok belajar (tim asal yang masing-masing anggotanya memiliki keahlian). Mereka berbagi keahlian. Tiap tim ahli mempresentasikan hasil diskusi pada anggota di kelompok asal. Fase diskusi dalam kelompok ini berlansung lebih kurang 40 menit.

f. Fase keenam, evaluasi dilakukan oleh guru sekitar 20 menit

\section{KESIMPULAN DAN SARAN A. Kesimpulan}

Berdasarkan hasil analisis data dan pembahasan yang telah diuraikan pada bab sebelumnya, maka dapat disimpulkan bahwa pembelajaran kooperatif tipe Jigsaw memberikan dampak positif terhadap peningkatan hasil belajar PKn dan terjadi perubahan aspek kognitif yang meningkat pada murid kelas IV SDN Sudirman IV Makassar selama pelaksanaan tindakan. Hal ini dapat terlihat pada hasil belajar PKn murid kelas IV SDN Sudirman IV Makassar melalui pembelajaran kooperatif tipe Jigsaw mengalami peningkatan. Hal ini terlihat dari nilai rata-rata setelah dilaksanakannya tindakan kelas pada siklus I, kemudian nilai rata-rata meningkat dari skor ideal setelah dilaksanakannya tindakan kelas pada siklus II. Ketuntasan Hasil belajar PKn murid kelas IV SDN Sudirman IV Makassar meningkat. Dari siklus I ke siklus II mencapai ketuntasan hasil belajar PKn dari indikator keberhasilan yang telah ditentukan.

\section{B. Saran}

1. Pada penelitian ini sebaiknya seorang guru harus mampu menciptakan suasana tenang dan menarik perhatian murid di dalam kelas. Suasana tenang bisa tercipta apabila memberikan motivasi pada murid dan menggunakan model pembelajaran sesuai dengan materi yang diajarkan. Salah satu yaitu model pembelajaran kooperatif tipe Jigsaw yang dapat menarik perhatian dan menyenangkan murid dalam pembelajaran.

2. Penelitian ini hendaknya dapat dilanjutkan oleh peneliti lain yang berminat dan memperhatikan kekurangan-kekurangan yang ada pada penelitian ini, pada subjek serta pada objek penelitian yang berbeda demi peningkatan kualitas pembelajaran ke depan.

3. Pada pihak sekolah sebaiknya memberikan pelatihan kepada guruguru mengenai model-model pembelajaran salah satunya model pembelajaran kooperatif tipe Jigsaw sehingga dapat menerapkan di kelasnya masing-masing.

\section{DAFTAR PUSTAKA}

Asep Jihad. 2008. Evaluasi Pembelajaran. Yogyakarta: Multi Press

Aunurrahman. 2009. Belajar dan Pembelajaran. Bandung : Alfabeta

Anas Sujiono. 2008. Pengantar Evaluasi Pendidikan. Jakarta: PT. Raja Grafindo Persada

Dewa Kehet Setiadi. 2008. Interaksi \& Motivasi Belajar Mengajar. 
Jakarta: PT. Raja Grafindo Persada

Emzir. 2009. Metodologi Penelitian Pendidikan Kuantitatif \& Kualitatif. Surabaya: Bumi Aksara

Hisyam Zaini, Bernawy Munthe dan Sekar Ayu Aryani. 2008. Strategi Pembelajaran Aktif. Yogyarakta: Pustaka Insan Madani

Idris Shaffat. 2009. Optimazed Learning Strategy. Jakarta: Prestasi Pustaka Publisher

Muslimin Ibrahim, dkk. 2002. Pembelajaran Kooperatif. Surabaya: Universitas Negeri Surabaya
Ngalim Purwanto. 1990. Psikologi Pendidikan. Bandung: PT. Remadja Rosdakarya

Oemar Hamalik. 2001. teknik Pengukuran dan Evaluasi Pendidikan Bandung. Mandar Maju

Suharsini Arikunto. 1992. Dasar-dasar Evaluasi Pendidikan. Jakarta: Bumi Aksara

Shlomo Sharan. 2009. Handbook of Cooperative Learning. Yogyakarta: Imperium

Win Winger. 2000. Beyond Teaching \& Learning. Bandung 